\title{
Pengembangan Prototipe Sensor Elektromekanik Berbasis Prinsip Strain Gauge Menggunakan Poly(3,4-ethylenedioxythiophene):Poly(styrene sulfonic acid) (PEDOT:PSS)
}

\author{
Detiza Goldianto Octensi Hernowo dan Kuwat Triyana ${ }^{*}$ \\ Jurusan Fisika, FMIPA Universitas GadjahMada \\ Sekip Utara BLS.21 Yogyakarta, 55281 \\ ${ }^{*}$ email: triyana@ugm.ac.id
}

\begin{abstract}
Abstrak - Tujuan dari penelitian ini adalah untuk mengembangkan prototype sensor elektromekanik menggunakan polimer konduktif poly (3,4-ethylenedioxythiophene): poly (styrenesulfonate) (PEDOT: PSS). Sebelum melakukan fabrikasi dan karakterisasi sensor, pertama - tama dilakukan verifikasi homogenitas resistansi pada lapisan PEDOT:PSS yang dideposisikan pada substrat isolator. Pada kasus ini, uji homogenitas dilakukan pada 5 posisi berbeda di atas lapisan PEDOT:PSS. Fabrikasi sensor dilakukan pada PEDOT:PSS menggunakan metode drop-coating di atas substrat nitrile rubber. Hasil yang diperoleh pada resistivitas listrik relatif ternormalisasi dari sensor elektromekanik menunjukkan sifat linear terhadap strain sensor. Selain itu, resistivitas sensor dipengaruhi oleh perubahan suhu secara eksponensial pada rentang 30 $80{ }^{\circ} \mathrm{C}$.
\end{abstract}

Kata kunci: PEDOT:PSS, sensor elektromekanik, strain gauge

Abstract - The aim of this research is to develop a prototype of electromechanical sensor by employing conductive polymer poly (3,4-ethylenedioxythiophene): poly (styrenesulfonate) (PEDOT: PSS). Prior to the sensor fabrication and characterization, we first verified the resistance homogeneity of PEDOT:PSS layer deposited on an insulator substrate. In this case, the homogeneity test was performed at five different positions on the PEDOT:PSS layer. The sensor fabrication were carried out by using drop-coating method of PEDOT:PSS solution on nitrile rubber substrats. It is found that normalized relative electrical resistivity of the electromechanical sensor shows linearly to the strain. Moreover, the resistivity of sensor is affected by the change of temperature exponentially in the range of $30-80{ }^{\circ} \mathrm{C}$.

Key words: PEDOT:PSS, electromechanical sensor, strain gauge

\section{PENDAHULUAN}

Baru - baru ini telah banyak dikembangkan Sistem Mikro-Elektro-Mekanis (MEMS) yang merupakan bagian dari perangkat teknologi yang sangat kecil. MEMS seringkali digunakan sebagai mesin berskala mikro yang terdiri dari komponen berukuran 1 hingga 100 mikrometer. Perangkat MEMS sendiri pada umumnya berkisar pada ukuran 20 mikrometer dan terdiri dari unit sentral yang berfungsi untuk memproses data (seperti mikroprosesor) dan beberapa komponen lain yang berinteraksi dengan luar seperti mikrosensor. MEMS menjadi lebih praktis apabila dimodifikasi menjadi bahan semikonduktor dengan fabrikasi perangkat teknologi sebagai komponen pada pembuatan bahan elektronik.. Pada umumnya, MEMS digunakan untuk keperluan otomotif, industri, dan sensor. Perkembangan aplikasi MEMS bergantung pada pengembangan material yang digunakan termasuk polimer. Harga yang relatif rendah, mudah dibuat, suhu yang stabil, tingkat fleksibilitas tinggi dan kemampuan untuk fabrikasi ketebalan film sebesar 1-10 $\mu \mathrm{m}$ merupakan salah satu pengembangan polimer sintetis untuk MEMS. Pengembangan polimer konduktif mulai tersebar luas pada berbagai macam aplikasi di bidang mikorelektronik, electroluminescence, amplifier optis dan transistor organik. Komponen tunggal polimer seperti polypyrrole, polyimide, polydimethylsiloxane, poly(methyl methacrylate) dan polyvinyl alkohol (PVA) telah banyak digunakan pada aplikasi perangkat MEMS.

Selain MEMS, kebutuhan akan teknologi sensor elektromekanik fleksibel menjadi semakin tinggi. Generasi baru dari sensor cerdas telah didesain pada material fleksibel dikarenakan sensor konvensional dan gauge tidak sesuai dengan karakteristik mekanik secara umum dan tidak fleksibel seperti tekstil. Sensor yang digunakan sudah seharusnya sesuai sehingga dapat ditarik ataupun dibengkokkan pada substrat. Sensor seharusnya diintegrasikan pada struktur tekstil untuk dapat mengikuti semua deformasi mekanik tanpa mempengaruhi karakteristik tekstil original seperti kelembutan. Fiber optis, fiber polimer piezoelektrik, polimer konduktif dan komposit polimer konduktif adalah beberapa pengembangan yang dapat digunakan pada spesifikasi ini [1]. PEDOT:PSS merupakan salah satu contoh polimer konduktif yang sering digunakan pada berbagai macam aplikasi di bidang semikonduktor. Kegunaan PEDOT:PSS pada penelitian ini yakni sebagai lapisan pada aplikasi sensor elektromekanik fleksibel. 


\section{LANDASAN TEORI}

Polimer konduktif yang merupakan generasi terbaru dari polimer awalnya diproduksi pada tahun 1960. Polimer konduktif memiliki sifat optis, elektrik dan mekanik sama halnya dengan semikonduktor logam dan inorganik. Selain itu, polimer konduktif juga memiliki sifat seperti pada polimer konvensional yakni mudah disintesis dan fleksibel [2].

Pada tahun 2000, Alan Heeger, Alan MacDiarmid dan Hideki Shirakawa memperoleh hadiah nobel di bidang kimia atas penemuannya pada elaborasi polimer konduktif elektronik. Ketiga peneliti tersebut menyatakan bahwa polimer plastik dapat dibuat untuk menghantarkan listrik apabila atom karbon dihubungkan dengan ikatan tunggal atau ganda dan elektron lainnya dihilangkan melalui proses oksidasi atau reduksi.

Elektron pada ikatan lainnya dibatasi dan tidak dapat menghantarkan arus listrik, namun ketika ketiga peneliti tersebut memberikan doping pada material dengan akseptor elektron kuat seperti iodine, yang pada akhirnya polimer mulai menunjukkan sifatnya seperti logam dengan konduktivitas $10^{11}$ kali lebih tinggi daripada polyacetylene (PA) [3].

Polimer konduktif adalah polimer organik yang dapat menghantarkan arus listrik. Bahan - bahan tersebut biasanya merupakan material semikonduktif dengan konduktivitas seperti logam atau oksida logam. Polimer konduktif memiliki berbagai macam struktur dengan harga yang relatif murah, mudah dibuat dan dapat diproses secara mekanik [4]. Jenis polimer konduktif sangat banyak diantaranya yaitu, polyacetylene, polythiophene, polyaniline dll.

Keuntungan polimer konduktif dimanfaatkan untuk beberapa hal, diantaranya yaitu :

1. Polimer konduktif digunakan sebagai pengemas antistatis pada material elektronik untuk menghindari pelepasan listrik/ electrostatic discharge (ESD) yang dapat merusak komponen. Penggunaan material ini utamanya digunakan pada pengemasan konduktor ion dan plastik logam.

2. Polimer konduktif dapat juga digunakan pada aplikasi teknologi perangkat elektrokromik. Elektrokromik dapat dijelaskan sebagai sifat optis dari material atau sistem yang dialiri dengan arus listrik.

3. Polimer konduktif juga dapat digunakan sebagai sensor elektromekanik yang memiliki sifat resistivitas seperti yang ditunjukkan pada persamaan (1).

$\rho=\frac{R \cdot A}{\ell}$

Selain itu, untuk menghitung nilai resistivitas listrik relatif ternormalisasi dan strain relatif sensor dapat dilakukan menggunakan persamaan (2) dan (3).

$$
R_{r}=\frac{\left(R-R_{i}\right)}{R_{i}}
$$

Dimana : $\mathrm{R}_{\mathrm{r}}=$ Resistivitas listrik relatif ternormalisasi

$$
\mathrm{R}=\text { Resistansi }(\Omega)
$$

$$
\mathrm{R}_{\mathrm{i}}=\text { Resistansi awal }(\Omega)
$$

$$
\varepsilon_{r}=\frac{\left(l-l_{i}\right)}{l_{i}}
$$

Dimana : $\varepsilon_{\mathrm{r}}=$ strain relatif $(\mathrm{mm} / \mathrm{mm})$

$$
\begin{aligned}
& 1=\text { panjang bahan }(\mathrm{mm}) \\
& \mathrm{l}_{\mathrm{i}}=\text { panjang awal bahan }(\mathrm{mm})
\end{aligned}
$$

Untuk menghitung faktor gauge dari sensor dapat dilakukan menggunakan persamaan (4).

$$
R_{r}=K . \varepsilon_{r}
$$

dengan $\mathrm{K}$ adalah Faktor gauge

PEDOT:PSS merupakan salah satu contoh polimer konduktif baru yang memiliki sifat elektrokimia yang baik dan suhu yang relatif stabil. PEDOT dibentuk dari monomer ethylenedioxythiophene (EDOT). Poly(styrenesulfonic acid) atau yang sering disebut dengan PSS merupakan salah satu jenis ion pembalik. PEDOT:PSS merupakan bentuk kombinasi dari perpaduan antara PEDOT dan PSS. PEDOT:PSS sendiri memiliki 3 sifat utama sebagai polimer konduktif, yakni sifat optis, sifat elektrik dan sifat mekanik [5].

Strain gauge adalah komponen elektronika yang dipakai untuk mengukur tekanan (deformasi atau strain). Alat ini berbentuk foil logam atau kawat logam yang bersifat insulatif (isolasi) dan ditempel pada benda yang akan diukur tekanannya. Prinsipnya adalah jika tekanan pada benda berubah, maka foil atau kawat akan terdeformasi dan tahanan listrik alat ini akan berubah [6].

Sel beban (load cell) terdiri dari satu buah strain gauge atau lebih yang ditempelkan pada batang atau cincin logam. Sel beban dikalibrasikan oleh pabrikan yang bersangkutan. Piranti ini dirancang untuk mengukur gaya tekanan mekanis, gaya pemampatan (kompresi) atau gaya puntir yang bekerja pada sebuah objek. Ketika batang atau cincin logam piranti ini berada di bawah tekanan, tegangan yang timbul pada terminal - terminalnya dapat dijadikan rujukan untuk mengukur besarnya gaya. Sel - sel beban seringkali digunakan untuk menimbang berat suatu objek. Tipe - tipe kelas berat dapat digunakan untuk menimbang bobot sebesar ratusan atau bahkan ribuan kilogram. Pada sebuah weight bridge atau jembatan penimbang, sel - sel beban semacam ini digunakan untuk menimbang kendaraan dengan bobot muatan yang sangat besar.

\section{METODE PENELITIAN}

Pengukuran resistivitas dilakukan dengan menggunakan konsep strain gauge. Substrat nitrile rubber yang digunakan merupakan substrat dengan tingkat elastisitas yang cukup tinggi sehingga tidak mudah sobek ketika diberi beban yang cukup berat. Substrat nitrile rubber dicuci terlebih dahulu dengan isoprophyl alkohol menggunakan ultrasonic cleaner hingga tidak ada sedikit pun lemak yang menempel. Setelah dicuci bersih, substrat dikeringkan dengan cara di-anginanginkan dan diteteskan material PEDOT:PSS yang telah tersedia. Pengukuran resistivitas dilakukan dengan cara menghitung terlebih dahulu nilai resistansi pada multimeter. 
Pengukuran resistansi dilakukan dengan menghubungkan kawat penghubung yang telah di-amplas hingga tidak ada sedikit pun lapisan isolatif yang melapisinya. Konsep pemasangan substrat dilakukan dengan menggantungkan substrat nitrile rubber pada statis yang dijepit dengan penjepit dan diberikan beban pada substrat yang variatif dari 5 gram hingga 50 gram dengan kenaikan 5 gram di setiap titik datanya. Pemberian beban pada substrat nitrile rubber dimaksudkan agar lapisan PEDOT:PSS yang menempel mengalami deformasi sehingga akan berpengaruh terhadap nilai resistansi dan resistivitasnya.

Selain diberi beban, langkah selanjutnya yakni dengan melakukan variasi suhu menggunakan hot plate yang ada di Laboratorium Fisika Material dan Instrumentasi, Universitas GadjahMada. Pengukuran resistivitas dengan variasi suhu dilakukan dengan pemberian suhu mulai dari $5^{\circ} \mathrm{C}$ hingga $50^{\circ} \mathrm{C}$ dengan kenaikan sebesar $5^{\circ} \mathrm{C}$. Dari setiap hasil yang diperoleh, nilai resistansi yang terukur pada multimeter digital yang disambungkan dengan kawat penghubung kemudian dicatat dan dianalisis lebih lanjut untuk dihitung nilai resistivitas yang diperoleh.

\section{HASIL DAN PEMBAHASAN}

Pengukuran resistansi PEDOT:PSS dilakukan dengan mengukur terlebih dahulu nilai resistansi yang diperoleh.

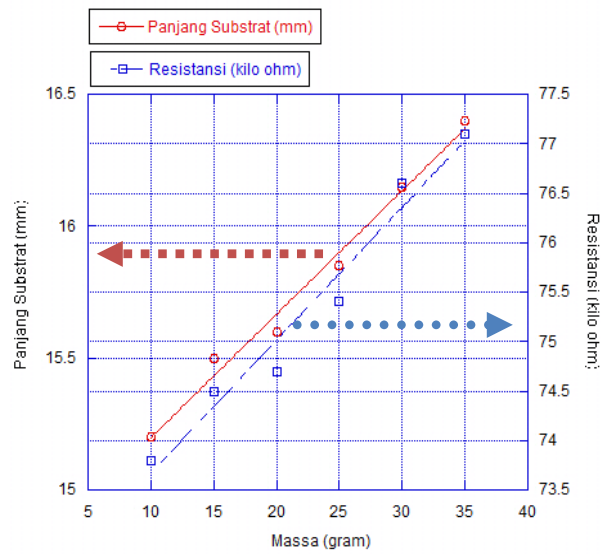

Gambar 1. Profil hubungan panjang substrat terhadap variasi beban

Gambar 1 menunjukkan perubahan panjang substrat nitrile rubber dan resistansi yang diperoleh. Kedua garis pada grafik tersebut menunjukkan sifat linear pada pemberian beban 10 - 35 gram dimana semakin besar massa yang diberikan, maka akan semakin besar pula nilai resistansi dan panjang substrat yang diperoleh. Hal ini sesuai dengan persamaan 2.1 dimana nilai resistansi $\mathrm{R}$ selalu berbanding lurus dengan panjang 1 dan berbanding terbalik dengan luas penampang A. Namun, pada pemberian beban di atas 40 gram, garis yang terbentuk mulai mengarah ke garis horizontal (untuk panjang substrat) dan garis vertikal (untuk resistansi) hingga tak terhingga nantinya. Hal ini disebabkan karena PEDOT:PSS memiliki daya regang terbatas. PEDOT:PSS akan menjadi tidak stabil ketika diberi beban yang terlalu berat. Pada proses pengambilan data di atas, penelitian yang dilakukan memiliki sifat repeati 3 yang rendah sehingga PEDOT:PSS bersifat disposal. Fıаı ııı dikarenakan pada proses pemberian beban, substrat yang digunakan memiliki tingkat elastisitas tertentu yang tidak dapat kembali sama persis seperti kondisi semula.

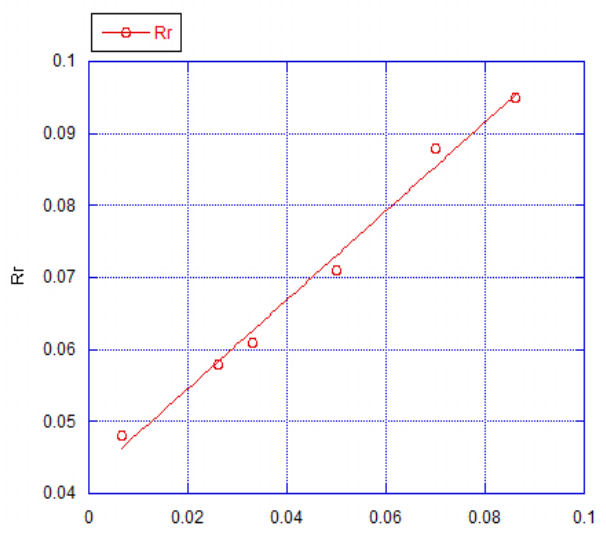

Gambar 2. Profil hubungan resistıvıtas listrik $\left(\mathrm{R}_{\mathrm{r}}\right)$ terhadap strain sensor $\left(\varepsilon_{\mathrm{r}}\right)$

Gambar 4 menjelaskan hubungan antara $\varepsilon_{\mathrm{r}}$ terhadap $\mathrm{R}_{\mathrm{r}}$ pada pengukuran resistansi dengan perubahan beban yang menunjukkan sifat elektromekanik suatu bahan. Sifat elektromekanik sendiri didefinisikan sesuai persamaan 2.2 dimana $R_{r}$ merupakan nilai resistivitas listrik relatif ternormalisasi yang menjelaskan karakterisasi sifat listrik pada sensor. Sifat mekanik pada sensor didefinisikan sesuai persamaan 2.3 dimana $\varepsilon_{\mathrm{r}}$ menyatakan strain relatif. Hasil penelitian yang telah diperoleh kemudian diplot ke dalam grafik menggunakan persamaan 2.2 dan 2.3 untuk dianalisis lebih lanjut sehingga terbentuk sifat elektromekanik yang merupakan perpaduan diantara keduanya. Grafik yang terbentuk mengalami kenaikan drastis seiring adanya perubahan strain sensor.

Penelitian selanjutnya yakni dengan mengukur nilai resistansi PEDOT:PSS yang diperoleh dengan adanya variasi suhu.

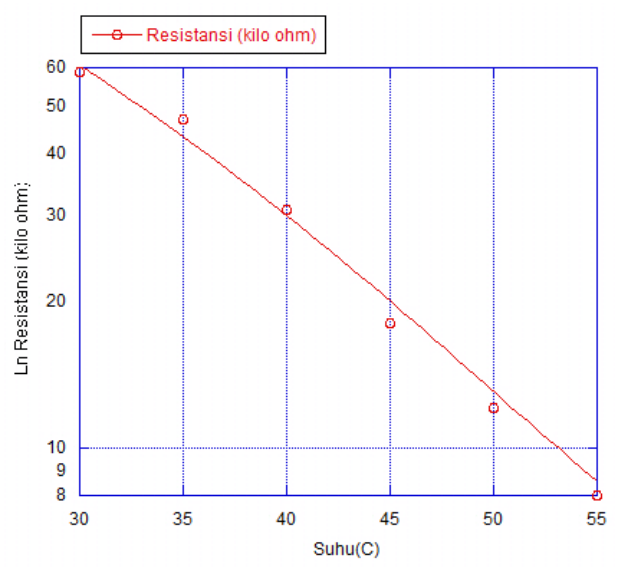

Gambar 3. Profil hubungan resistansi terhadap pengaruh suhu 
Gambar 3 menunjukkan grafik pengukuran resistansi terhadap perubahan suhu. Penelitian ini menunjukkan hasil yang cukup berbeda dengan pengukuran resistansi dan panjang substrat yang dilakukan pada penelitian strain gauge terhadap variasi beban. Pengukuran resistansi yang dilakukan ternyata menunjukkan hasil yang berbanding terbalik dengan penelitian sebelumnya. Variasi suhu yang dilakukan berkisar dari suhu $30{ }^{\circ} \mathrm{C}$ hingga $80{ }^{\circ} \mathrm{C}$ dengan kenaikan $5{ }^{\circ} \mathrm{C}$ di setiap titik datanya. Pada awalnya, penurunan nilai resistansi yang diperoleh cukup drastis yakni mencapai 10 - $20 \mathrm{k} \Omega$ setiap kenaikan $5{ }^{\circ} \mathrm{C}$. Namun, pada suhu $50{ }^{\circ} \mathrm{C}$ ke atas, penurunan resistansi yang terjadi tidak terlalu tinggi. Pada suhu $80{ }^{\circ} \mathrm{C}$ ke atas, resistansi yang diperoleh mulai terlihat tidak stabil. Hal ini dibuktikan dengan nilai resistansi yang menjadi naik bila dibandingkan dengan suhu sebelumnya. Hal yang mengakibatkan resistansi yang terjadi menjadi naik yakni karena partikel partikel penyusun lapisan PEDOT:PSS mulai pecah dan tidak kontak dengan partikel - partikel lainnya. Pengaruh suhu yang terlalu tinggi mampu menyebabkan konduktivitas dan sifat elektrik dari PEDOT:PSS menjadi tak beraturan.

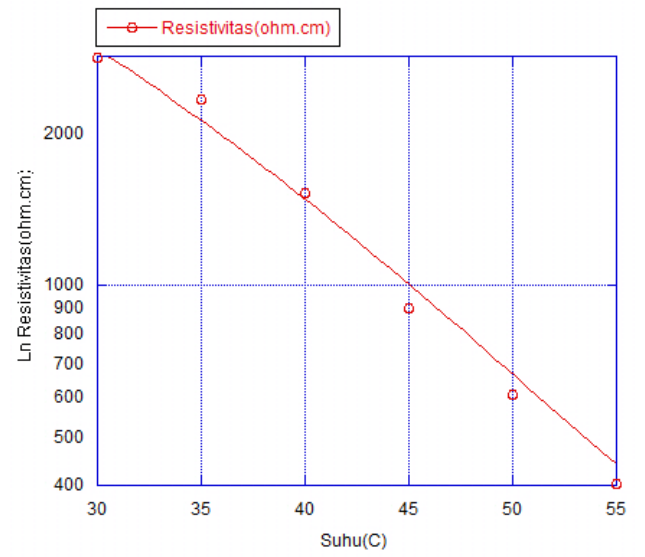

Gambar 4. Profil hubungan resistansi terhadap pengaruh suhu

Sama halnya dengan gambar 3, gambar 4 menjelaskan hubungan antara resistivitas terhadap perubahan suhu. Berdasarkan persamaan 2.1 yang menyatakan bahwa kesebandingan antara nilai resistansi yang disimbolkan dengan $\mathrm{R}$ dan resistivitas yang dilambangkan dengan $\rho$. Seiring dengan adanya perubahan resistansi, maka nilai resistivitas yang diperoleh pun akan sama sehingga gambar 4 merepresentasikan kesebandingan antara resistivitas dan resistansi. Pengukuran yang dilakukan menunjukkan bahwa nilai resistivitas mengalami penurunan yang cukup signifikan karena pengaruh suhu. Berdasarkan referensi yang diperoleh, spesifikasi polimer konduktif PEDOT:PSS tipe AI 4083 memiliki nilai resisitivitas sebesar $500-5.000$ $\Omega . c m$. Namun, hal ini cukup berbeda pada suhu $55-80^{\circ} \mathrm{C}$ dimana pada suhu tersebut resistivitas yang terukur kurang dari $500 \Omega . \mathrm{cm}$. Ada beberapa faktor yang menjadi sumber ketidakpastian terbesar pada hasil yang diperoleh, yakni :

1. Material PEDOT:PSS sangat sensitif terhadap pengaruh suhu dan rentan mengalami cacat yang mengakibatkan nilai resistivitas yang diperoleh tidak sesuai dengan referensi maupun literature.

2. Efek menyusut pada PEDOT:PSS yang diiringi dengan memendeknya substrat ketika diberi suhu yang lebih tinggi menyebabkan panjang 1 yang terukur sangat kecil dan tidak terlalu signifikan.

Peristiwa pecahnya partikel - partikel penyusun dalam lapisan PEDOT:PSS berpengaruh cukup besar terhadap nilai resistivitas yang diperoleh karena adanya peningkatan suhu.

\section{KESIMPULAN}

Dari uraian yang telah dijelaskan pada bab - bab sebelumnya, dapat disimpulkan bahwa :

1. Telah berhasil dilakukan penelitian resistivitas terhadap perubahan massa dan pengaruh suhu. Penelitian ini menghasilkan nilai resistivitas yang berkisar antara 3.300 - $3.500 \Omega . c m$ untuk perubahan massa. Sedangkan pada pengaruh suhu, diperoleh nilai resistivitas berkisar antara $200-2.900 \Omega$.cm. Hal ini menunjukkan bahwa ketebalan lapisan di setiap titik pada PCB tidak homogen.

2. Telah diperoleh profil hubungan panjang dan resistansi terhadap perubahan massa dan pengaruh suhu. Pada penelitian tersebut, diperoleh kurva linear untuk resistansi dan panjang terhadap perubahan massa dari rentang 10 - 35 gram. Namun, hal ini berbanding terbalik untuk pengukuran panjang dan resistansi terhadap perubahan suhu. Semakin tinggi suhu yang diberikan, maka semakin kecil resistansi dan panjang yang diperoleh. Sifat linear pada perubahan suhu terjadi pada suhu $30{ }^{\circ} \mathrm{C}-55^{\circ} \mathrm{C}$.

3. Telah diperoleh grafik hubungan resistansi terhadap suhu. Grafik tersebut menunjukkan kesamaan fenomena transport yang terjadi pada bahan semikonduktor sehingga PEDOT:PSS merupakan polimer konduktif yang termasuk golongan semikonduktor.

\section{PUSTAKA}

[1] [1] C. Cochrane, V. Koncar, M. Lewandowski, dan C. Dufour, Design and Development of a Flexible Strain Sensor for Textile Structures Based on a Conductive Polymer Composite. Sensor, 2007, 1424-8220.

[2] [2] H. Shirakawa, E.J. Louis, A.G. MacDiarmid, C.K. Chiang, dan A.J. Heeger, J.Chem. Soc. Chem. Commun. 1977, 578

[3] [3] D. Kumar dan R.C. Sharma, Advances in Conductive Polymers. Eur. Polym. J.Vol. 34,.8, 1998, 1053-1060.

[4] [4] J. Maron, M.J. Winokur, dan B.R. Mattes, 1995, Handbook of Macromolecules. 28,4475.

[5] [5] C.L. Chang, K. Fix, dan W,C. Wang, Reliability of PEDOT-PSS Strain Gauge on Foam Structure. Proc Soc Photo Opt Instrum Eng. 2010, 7646: 764616.

[6] [6] R. Mateiu, M. Lillemose, T.S. Hansen, A. Boisen, dan O. Geschke, Reliability of poly 3,4-ethylenedioxythiophene Strain Gauge. Microelectronic Engineering, 84, 2007, 12701273 